\title{
Potential effects of fungicide and algaecide extracts of Annona glabra L. (Annonaceae) on the microalgae Raphidocelis subcapitata and on the oomycete Pythium
}

\author{
GISELI S. ROCHA ${ }^{1, *}$, REGINALDO S. MATSUMOTO ${ }^{2}$, ANA TERESA LOMBARDI ${ }^{2}$ and MARIA INÊS S. LIMA ${ }^{2}$ \\ ${ }^{1}$ Departamento de Hidrobiologia, Universidade Federal de São Carlos, Rodovia \\ Washington Luís, SP-310, Km 235, 13565-905 São Carlos, SP, Brazil \\ ${ }^{2}$ Departamento de Botânica, Universidade Federal de São Carlos, Rodovia Washington \\ Luís, SP-310, Km 235, Caixa Postal 676, 13565-905 São Carlos, SP, Brazil
}

Manuscript received on January 20, 2016; accepted for publication on June 1, 2016

\begin{abstract}
Annona glabra L. is a semi-deciduous tree that contains several active substances, including secondary metabolites, with antifungal activity. Phytopathogenic strains of the genus Pythium cause billion dollar losses all over the world on natural and crop species. Searching for eco-friendly algaecides and fungicides, we analyzed the effects of acetone extracts of $A$. glabra leaves on the algae Rhaphidocelis subcapitata (Korshikov) and on the oomycete Pythium aphanidermatum (Edson). We evaluated ten extract concentrations for each organism - 0 to $400 \mathrm{mg} \mathrm{L}^{-1}$ for algae and 0-1000 $\mu \mathrm{g} \mathrm{disc}^{1}$ for oomycete. The results showed no effect on algae up to $75 \mathrm{mg} \mathrm{L}^{-1}$, but a significant inhibitory effect at $125 \mathrm{mg} \mathrm{L}^{-1}$ and above, which reduced the growth rate and the final biomass of the algae. Extract concentrations above $200 \mathrm{mg} \mathrm{L}^{-1}$ were completely inhibitory. The half maximal inhibitory concentration for 72 and $96 \mathrm{~h}$ of exposure to our crude extracts are comparable to those obtained with commercial fungicides and herbicides used in aquatic ecosystems. The $P$. aphanidermatum inhibition concentrations have effects comparable to fungicides as Cycloheximide and Bifonazole. Some substances isolated from the extracts are described as antifungals, which could explain part of anti-oomycete activity. Our results highlight the importance of searching bioactive compounds from plants.
\end{abstract}

Key words: algal growth, allelopathy, leaf extract, secondary metabolites.

\section{INTRODUCTION}

Annona glabra L. (Fig. 1) is a semi-deciduous plant adapted to flooded environments, including brackish- and saltwater, native from tropical America and West Africa (Pinto et al. 2005), present

Correspondence to: Giseli Swerts Rocha

E-mail: swertsbio@gmail.com

*Present Address: WasserCluster, Biologische Station Lunz, Dr. Carl Kupelwieser Promenade 5, 3293 Lunz am See, Austria in tropical and subtropical swampy environments, such as Florida (USA), Caribbean, Central and South America (Allen et al. 2002) and being considered invasive in Asia and Oceania (Mielke et al. 2005, Sugars et al. 2006). This species forms clusters along coastal wetlands and its fruits produce several seeds that germinate better in sunny conditions (Mata and Moreno-Casasola 2005, Setter et al. 2008). A. glabra has been reported to have parasiticide and insecticide activity, which 
supports its use in traditional medicine (Liu et al. 1999, Mendonça et al. 2005). Some of its isolated compounds have antimicrobial, antifungal, and anticancer properties (Padmaja et al. 1995, Zhang et al. 2004). Previous studies in our laboratory showed an allelopathic potential of the leaf extracts of A. glabra to the germination of weed species and etiolated wheat coleoptile (Matsumoto et al. 2010, 2014).

A. glabra has glabrous leaves, which may favor the leaking and leaching of intracellular compounds (Gross 2003). Several studies on allelopathy in aquatic ecosystems pointed to an influence of macrophytes on algae through in situ and laboratory experiments (Macías et al. 2007, Wu et al. 2009, Zhang et al. 2011).

An excess of nutrients in water bodies stimulates plant growth, accelerates eutrophication, and may lead to explosive phytoplankton growth with negative environmental impacts. As immediate consequences, we observe a decrease in water quality and a reduction of light penetration. In addition, depending on the dominant algae species, toxins may be released, affecting the biota (Hu and Hong 2008). Thus, the search for specific, natural products from plants that reduce microalgae growth is important for the control of phytoplankton blooms in the environment. Plants and their secondary metabolites are good candidates (Zhu et al. 2010).

Oomycetes has been recently separated from Fungi kingdom, and contain several plants pathogens, such as Phytophthora and Pythium (Van West et al. 2013). Most of phytopathogenic Pythium species often live in wet or flood soil conditions and causes fruit, root or collar rot and seedlings damping-off (Nechwatal and Mendgen 2007). Pythium aphanidermatum is a filamentous organism that causes severe diseases in many plant species and responsible for huge economic losses in agriculture worldwide - fruit trees, sugarcane (Hendrix and Campbell 1973), rice
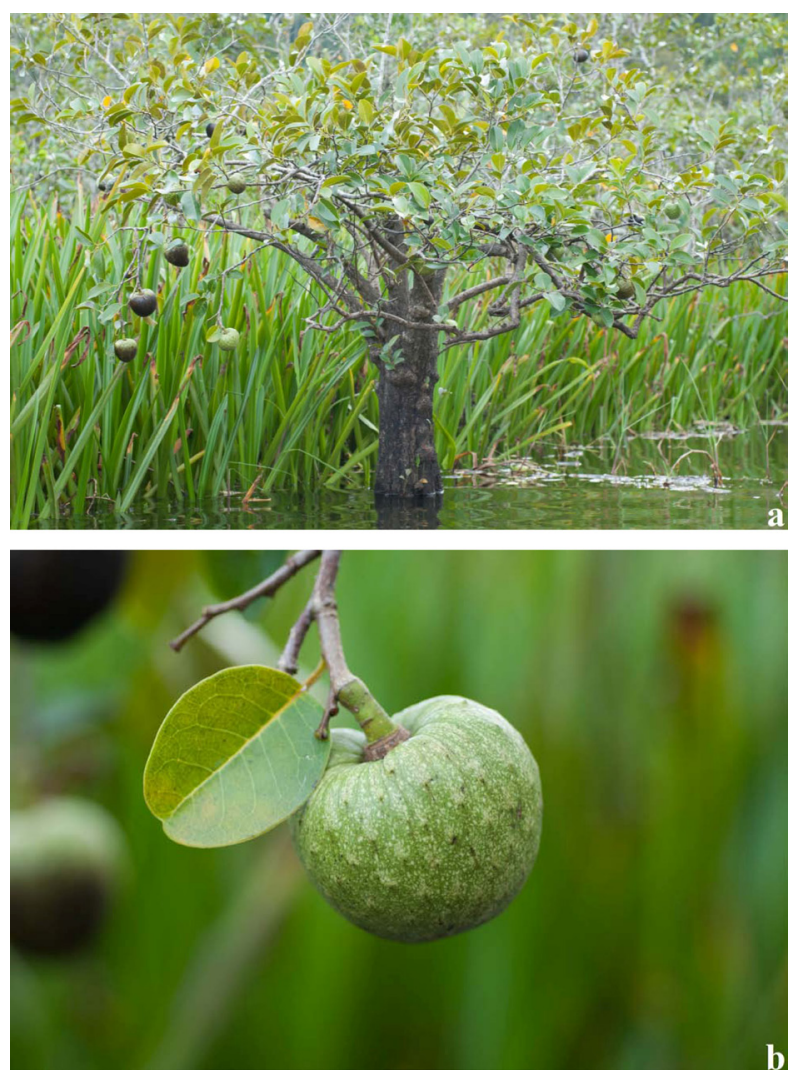

Figure 1 - Annona glabra tree (a) and fruit (b) in the Massaguaçu River Estuary, Brazil (2337'20”S and 54²1'25”W).

(Eberle et al. 2007), soybean and corn (Broders et al. 2007), carrots (Barr and Kemp 1975) and some hydroponic crop culture, as lettuce and tomato (Patekoski et al. 2010). The control of these pathogens is traditionally based on fungicides and chemical substances, however, biological control using endophytic actinomycetes (El-Tarabily et al. 2009) or bacteria (Paulitz et al. 1992) showed promising results under controlled conditions (i.e. in vitro experiments).

Long term application of synthetic chemicals for pest control cause food and environmental contamination due to their residues and slow degradation and the search for effective natural substances to control plant fungal diseases is very important (Salamci et al. 2007, Pawar 2011). According to $\mathrm{Lu}$ et al. (2008) and Duke et al. (2010) natural toxins are environmentally and 
toxicologically safer molecules than synthetic toxins, because they do not have potentially dangerous substances in their composition while chemical algaecides have broad toxicity to aquatic organisms and can persist in the environment, whereas natural products may be more specific and less toxic to higher trophic levels. Some of the advantages of using natural compounds to control phytoplankton populations are that they do not have toxic metals, pro-oxidants, and organic amines in their composition, in contrast to the chemical algaecides available in the market.

After extraction, 8 compounds were isolated and identified from A. glabra leaves extract: (1) ent-kaur-16-en-19-oic acid; (2) $\beta$-sistosterol; (3) stigmasterol; (4) ent-19-methoxy-19-oxokauran17-oic acid; (5) annoglabasin B; (6) ent-17hydroxykaur-15-en-19-oic acid; (7) ent-15 $\beta, 16 \beta$ epoxy-17-hydroxy-kauran-19-oic acid and (8) asimicin. Substances 4 and 5 affected the elongation of wheat coleoptile with similar results compared with the commercial herbicide Logran ${ }^{\mathrm{TM}}$. The authors suggested that these substances can act as defense mechanisms in A. glabra protecting it from microorganisms that live in the same environment - flooded area (Matsumoto et al. 2014).

Traditionally, studies on plant allelopathy and toxicity to aquatic organisms (e.g., microalgae and cyanobacteria) use more frequently aquatic plants (e.g., macrophytes) than tree species as sources. The present research aimed at evaluating the effect of leaf extracts of Annona glabra on microalgae Raphidocelis subcapitata (Korshikov) and on oomycete Pythium strains.

\section{MATERIALS AND METHODS}

The adult plant of $A$. glabra and their healthy leaves were obtained from trees in the Massaguaçu River Estuary, Brazil (2337'20'S and 54'21'25''W). We deposited the voucher specimen 7503 in the herbarium of Departamento de Botânica, at Universidade Federal de São Carlos. After collection, the leaves were dried in a greenhouse at $45^{\circ} \mathrm{C}$ for $48 \mathrm{~h}$, ground and the powder stored in a freezer at $-20^{\circ} \mathrm{C}$ until extraction.

Active compounds of A. glabra from $1.0 \mathrm{~g}$ of ground and dried samples were extracted using an ultrasound assisted extraction (UAE) procedure, following Firdaus et al. (2010). The extraction method recovers organic compounds, including those with allelopathic potential, such as alkaloids and flavonoids. The UAE conditions were: $25 \mathrm{~mL}$ acetone, $2 \mathrm{~mm}$ probe, cycle of $0.2,30 \%$ amplitude of $200 \mathrm{~W}$, and instrument potency of $24 \mathrm{~Hz}$. These conditions were applied during 20 minutes at $5{ }^{\circ} \mathrm{C}$.

To evaluate the effects of leaf extracts of $A$. glabra on $R$. subcapitata, toxicity tests were performed with extract concentrations ranging from 25 to $400 \mathrm{mg} \mathrm{L}^{-1}(25,50,75,125,150,175$, 200, 300 and 400). After extraction procedure, we did a stock solution of extract in acetone (400 $\mathrm{mg} \mathrm{L}^{-1}$ ) and serial dilutions to obtain $50 \mathrm{~mL}$ of each test concentration (from 25 to $400 \mathrm{mg} \mathrm{L}^{1}$ ), while the control had no extract addition, but 50 $\mathrm{mL}$ of acetone. We made three replicates for each treatment. Approximately $50 \mathrm{~mL}$ of the extract were placed in $150 \mathrm{~mL}$ Erlenmeyer flasks that were vacuum dried at $35^{\circ} \mathrm{C}$ to volatilize the solvent. After complete dryness, when only the tested organic compound remained, $50 \mathrm{~mL}$ of exponentially growing $R$. subcapitata culture were added as inoculum.

Stock cultures of $R$. subcapitata were kept in LC Oligo culture medium (AFNOR 1980) under laboratory-controlled conditions of light intensity $\left(130 \mu \mathrm{mol}\right.$ photons $\left.\mathrm{m}^{-2} \mathrm{~s}^{-1}\right)$, light/dark cycle $(16: 8$ h), and temperature $\left(23 \pm 2^{\circ} \mathrm{C}\right)$. Hence, in the beginning of the experiment, each Erlenmeyer flask contained the dried extract and $5 \times 10^{4}$ cells $\mathrm{mL}^{-1}$. Bioassays were incubated under the same growth conditions as the algae stock cultures. Daily aliquots $(0.5 \mathrm{~mL})$ were obtained up to $96 \mathrm{~h}$ of exposure to estimate algae biomass (cell $\mathrm{mL}^{-1}$ ). 
Algae cells were counted in an Improved Neubauer chamber under optical microscope and growth rates obtained by plotting the natural log of cell $\mathrm{mL}^{-1}$ against experimental time and calculating a linear regression for the exponential part of the growth curve. Growth rate values were calculated as the slopes of linear regressions. The inhibitory concentration that caused $50 \%\left(\mathrm{IC}_{50}\right)$ of decrease in $R$. subcapitata biomass were estimated at 72 and $96 \mathrm{~h}$ of exposure.

Pure isolate of Pythium aphanidermatum strain CCMA 243 (Laboratório de Microbiologia Ambiental - Embrapa Meio Ambiente - CNPMA) was cultured in PDA (potato dextrose agar). Plates were disposed in culture chambers at $25 \pm 2{ }^{\circ} \mathrm{C}, 12$ $\mathrm{h}$ photoperiod, until the growth reached the edge of an $85 \mathrm{~mm}$ Petri dish plate. Disc diffusion test was used to evaluate the anti-oomycete activity. A $5 \mathrm{~mm}$ diameter plug of the PDA with $P$. aphanidermatum was transferred to the center of a Petri dish plate with PDA.

Six millimetres paper disks were soaked with $40 \mu \mathrm{L}$ of the extract, dried and disposed equidistant from the centre of the plate $(23 \mathrm{~mm})$. Three groups of plates were established (A, B and C). Each group received 4 discs with different concentrations of the extract: A - $0 ; 0.97 ; 1.95$ and 3.9; B - 7.8; 15.6; 31.2 and $62.5 ; \mathrm{C}-125 ; 250 ; 500$ and $1000 \mu \mathrm{g} \mathrm{disc}^{-1}$. The $0 \mu \mathrm{g}$ disc was soaked with $40 \mu \mathrm{l}$ of acetone and used as negative control. Four group replicates were applied and three PDA plates with an oomycete plug on the centre were prepared as growth control. The oomycete growth and inhibition zones (radius) were measured every $24 \mathrm{~h}$ for 15 days.

The final biomass of the treatments at $96 \mathrm{~h}$ of exposure of algae were contrasted through an ANOVA with a Tukey post hoc test, with the use of F statistics to compare growth rates. The oomycete growth after 15 days was fitted in Boltzmann equation and curves were compared with ANOVA. Inhibition radiuses were compared with ANOVA with Tukey's post hoc test.

\section{RESULTS}

Figure 2 shows cell density at $96 \mathrm{~h}$ of exposure as a function of extract concentration of A. glabra, as well as $\mathrm{IC}_{50}$ values for $72 \mathrm{~h}\left(135.6 \mathrm{mg} \mathrm{L}^{-1}\right)$ and $96 \mathrm{~h}$ of exposure $\left(145 \mathrm{mg} \mathrm{L}^{-1}\right)$. The results show that up to $75 \mathrm{mg} \mathrm{L}^{-1}$ no effects of the leaf extract of A. glabra were detected on R. subcapitata. Above this concentration, inhibition increased gradually with extract concentration, until reaching null microalgal growth at $200 \mathrm{mg} \mathrm{L}^{-1}$ and higher. No statistical difference was detected for the three highest concentrations tested.

Figure 3 shows cell density as a function of experiment duration. Since no significant difference (F test) was detected in the growth rates among replicates, the data could be pooled together and a single slope was calculated for each treatment. Figure 3 shows that at the extract concentrations of 125,150 , and $175 \mathrm{mg} \mathrm{L}^{-1}$ there was a delay in the population growth of $R$. subcapitata, analogous to a lag phase in standard batch cultures. So, we calculated linear regressions for the growth curves of the treatments after $24 \mathrm{~h}$ of exposure for 125 and $150 \mathrm{mg} \mathrm{L}^{-1}$, and after $48 \mathrm{~h}$ of exposure for 175 $\mathrm{mg} \mathrm{L}^{-1}$. For the treatments at the concentrations of 200, 300, and $400 \mathrm{mg} \mathrm{L}^{-1}$, algae cells were unable to divide, then no growth was observed and cell densities $\left(\sim 5 \times 10^{4}\right.$ cell $\left.\mathrm{mL}^{-1}\right)$ were statistically similar (ANOVA $\mathrm{p}>0.05$ ).

The fitted curves of controls and tested groups (A, B and C) of $P$. aphanidermatum present no difference, with similar final growth and growth rate. No inhibition zones were noticed on $\mathrm{A}$ and B groups (data not shown). The $\mathrm{C}$ group started presenting inhibition zones on day 7 , when the oomycete reached the discs and zones were measured, reaching the maximum inhibition in day 10 .

The radius data from inhibition zones were pooled to calculate the average and standard deviation for ANOVA comparison. From the day 


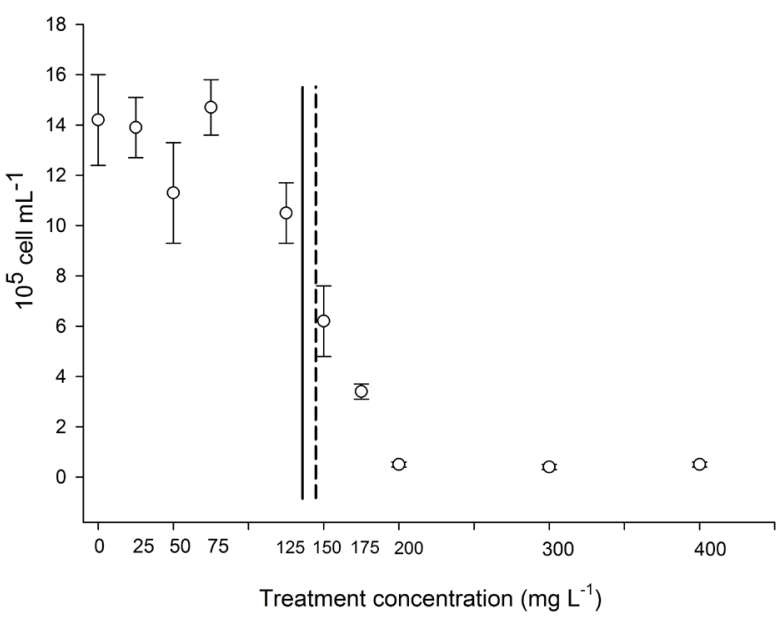

Figure 2 - Raphidocelis subcapitata culture density (cell $\mathrm{mL}^{-}$ $\left.{ }^{1}\right)$ at $96 \mathrm{~h}$ of exposure as function of extract concentration of Annona glabra $\left(\mathrm{mg} \mathrm{L}^{-1}\right)$. Continuous line represents the half maximal inhibitory concentration $\left(\mathrm{IC}_{50}\right)$ at $72 \mathrm{~h}$; dashed line represents $\mathrm{IC}_{50}$ at $96 \mathrm{~h}$.

11 to the end of experiment, the oomycete has recovered and grew over the discs and dissipating the inhibition zones, then occupying the whole plate. ANOVA comparisons showed differences among the four concentrations of $\mathrm{C}$ group (125, 250, 500 and $1000 \mu \mathrm{g} \mathrm{disc}^{-1}$ ), except between 500 and 1000, which present similar inhibition zones of $15.9 \pm 0.6$ and $16.4 \pm 1.3 \mathrm{~mm}$ respectively (Fig. 4).

\section{DISCUSSION}

Several commercial herbicides and fungicides bring risks to the environment. Harmful and long-term effects on aquatic organisms have been related to exposure to commercial herbicides. $\mathrm{The} \mathrm{IC}_{50}$ at 72 $\mathrm{h}$ of exposure of some of these particular products on $R$. subcapitata are between $270 \mathrm{mg} \mathrm{L}^{-1}$ and $100 \mathrm{mg} \mathrm{L}^{-1}$ ( ${ }^{\circledR}$ Bayer 2010, 2012). An assessment of the impacts of herbicides on non-target aquatic plants and algae, including $R$. subcapitata, showed $\mathrm{IC}_{50}$ values ranging from 0.055 to $270 \mathrm{mg} \mathrm{L}^{-1}$ (Cedergreen and Streibig 2005). Commercial algaecides as Barquat low foam presents $\mathrm{IC}_{50}$ of $0.04 \mathrm{mg} \mathrm{L}^{-1}$ against $R$. subcapitata $\left({ }^{\circledR}\right.$ Lonza 2004)
Our results corroborate the use of extract of plants inhibiting the growth of microalgae (e.g. leaf litter on growth of Chlorella vulgaris), affecting interactions in phytoplankton community in the natural environment, reducing cyanobacteria dominance with the use of barley (Ridge et al. 1999). Cantrell et al. (2005) analyzed the effects of a terrestrial herbaceous plant (Haplophyllum sieversii) on the growth of $R$. subcapitata and obtained that the complete inhibition occurred at concentrations above $100 \mathrm{mg} \mathrm{L}^{-1}$, while we observed the inhibition by the extract of A. glabra at concentrations above $200 \mathrm{mg} \mathrm{L}^{1}$.

There are several in situ and laboratory studies showing that macrophytes also can act as algae growth inhibitor (Hilt and Gross 2008, Toporowska et al. 2008), for example, ethyl acetate fractions of the macrophytes Potamogeton malaianus and P. maackianus were toxic to the cyanobacteria Microcystis aeruginosa at the concentration of $60 \mathrm{mg} \mathrm{L}^{-1}$, and reduced its biomass in $\sim 54 \%$ and $58 \%$, respectively (Wang et al. 2010). A study on the effects of aqueous extracts of five plant species on $R$. subcapitata, including Papaveraceae macrophytes, obtained $\mathrm{IC}_{50}$ at concentrations above $21 \mathrm{mg} \mathrm{L}^{-1}$. Stylophorum lasiocarpum was the fourth most active species, with $\mathrm{IC}_{50}$ at the concentration of $114 \mathrm{mg} \mathrm{L}^{-1}$ (Jančula et al. 2007). By comparing our results to those of Jančula et al. (2007), we can assume that the extracts of A. glabra, which are toxic at the concentration of $145 \mathrm{mg} \mathrm{L}^{-1}$, have a strong inhibitory effect. The $\mathrm{IC}_{50}$ of extracts of A. glabra on R. subcapitata in the present study was $135.6 \mathrm{mg} \mathrm{L}^{-1}$ and $145 \mathrm{mg} \mathrm{L}^{-1}$ for $72 \mathrm{~h}$ and 96 $\mathrm{h}$ of exposure. Hence, the plant Annona glabra is a promising species for the isolation of compounds with algaecide properties. As far as we know, this is the first study evaluating the algaecide effects of A. glabra extracts and those substances were not reported yet as algaecide. Table I summarizes the action of some extracts and pure products in tests on R. subcapitata. 

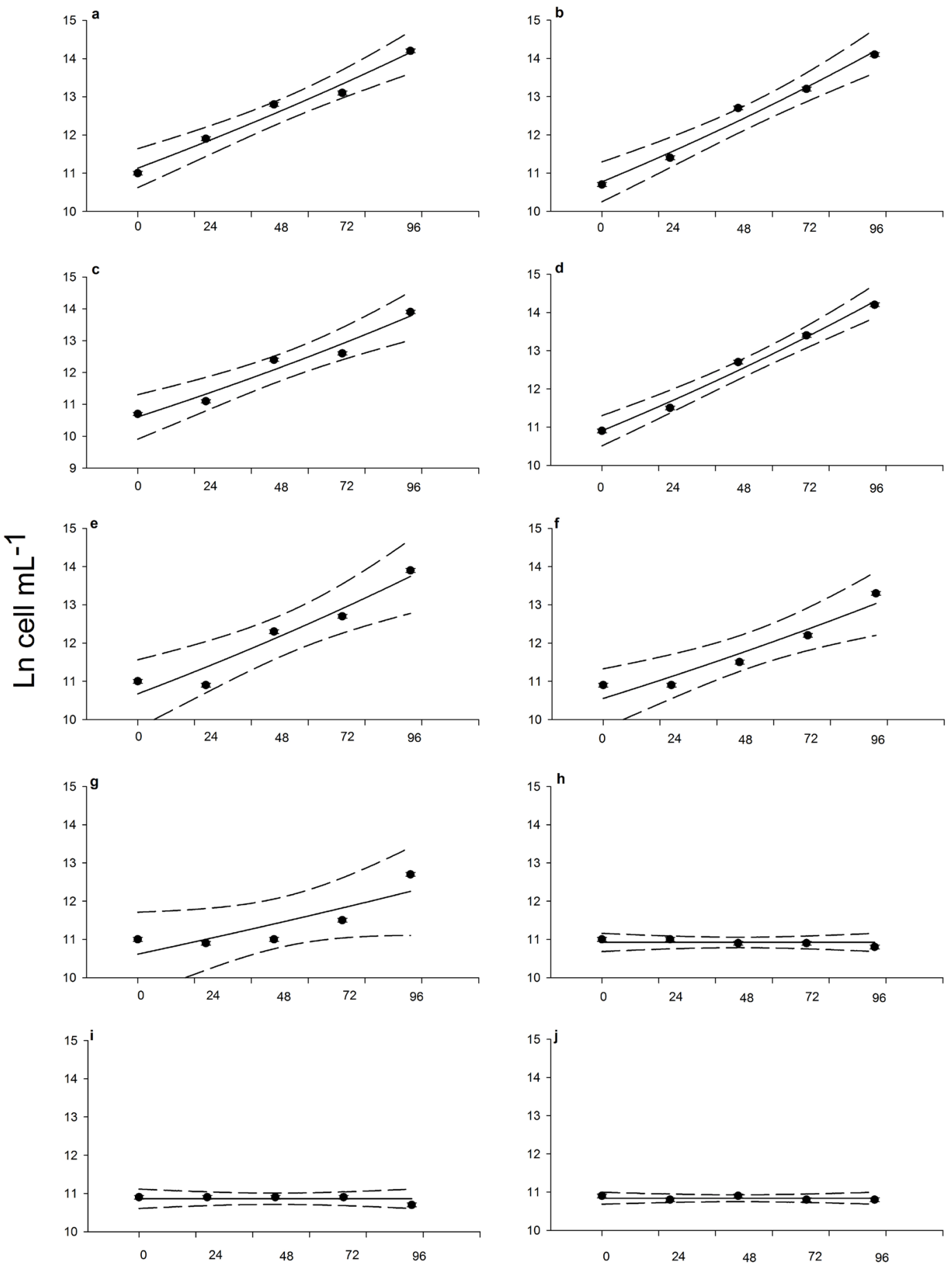

\section{Exposure time (h)}

Figure 3 - Raphidocelis subcapitata density $\left(\right.$ cell $\left.\mathrm{mL}^{-1}, \ln \right)$ as a function of exposure time (h) for each treatment. Values represent average ( $\pm \mathrm{SD})$ of $\ln \left(\right.$ cells mL $\left.\mathrm{m}^{-1}\right)$. (a) Control $\left(0 \mathrm{mg} \mathrm{L}^{-1}\right)$; (b) $25 \mathrm{mg} \mathrm{L}^{-1}$; (c) $50 \mathrm{mg} \mathrm{L}^{-1}$; (d) 75 $\mathrm{mg} \mathrm{L}^{-1}$; (e) $125 \mathrm{mg} \mathrm{L}^{-1}$; (f) $150 \mathrm{mg} \mathrm{L}^{-1}$; (g) $175 \mathrm{mg} \mathrm{L}^{-1}$; (h) $200 \mathrm{mg} \mathrm{L}^{-1}$; (i) $300 \mathrm{mg} \mathrm{L}^{-1}$; (j) $400 \mathrm{mg} \mathrm{L}^{-1}$ Annona glabra extract. Dashed lines represent $95 \%$ of confidence intervals. 
TABLE I

Comparison of the half maximal inhibitory concentration $\left(\mathrm{IC}_{50}\right)$ of extracts and compounds on Raphidocelis subcapitata Korshikov in toxicity assays.

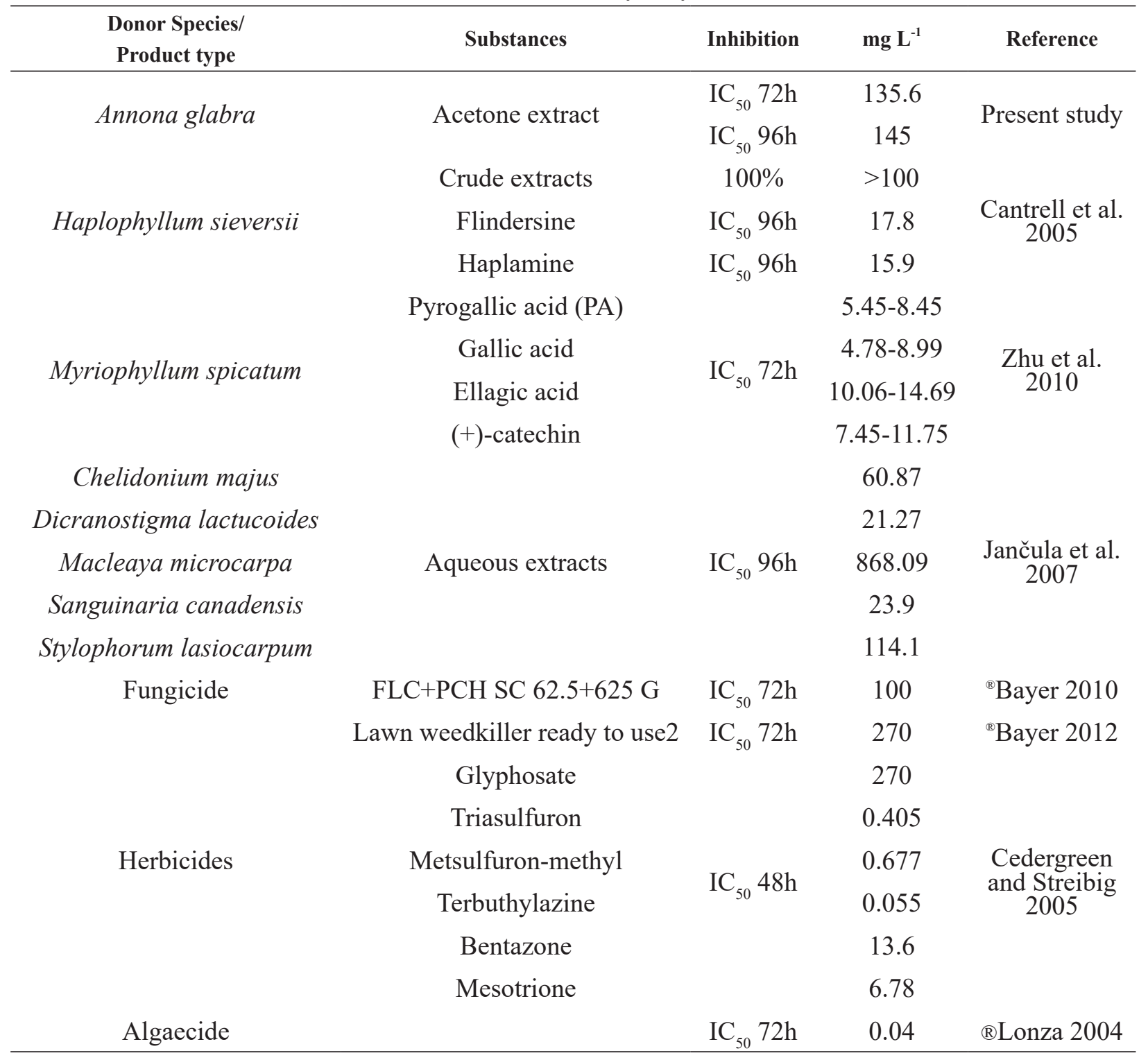

According to NRA (2001), R. subcapitata presented lower growth rate and delayed growth when exposed to $10 \mathrm{mg} \mathrm{L^{1 }}$ semduramicin (anticoccidial), whereas a total growth inhibition was observed at $39 \mathrm{mg} \mathrm{L}^{-1}$. In our study, a similar delay was observed before the beginning of the exponential growth phase when the algae were exposed to concentrations of $125-175 \mathrm{mg} \mathrm{L}^{-1}$ of the extract of $A$. glabra. However, after such a lag phase, the two highest growth rates were observed. This may be related to a survival strategy under a stressing situation, with the algae adjusting its metabolism to the presence of the toxic agent (Stebbing 1982, 1987). This author linked a similar behavior to what is known as the hormesis effect, whereby the toxicant at low doses can stimulate the organism. Phytochemicals exist to protect plants from oxidative and other types of stress, 


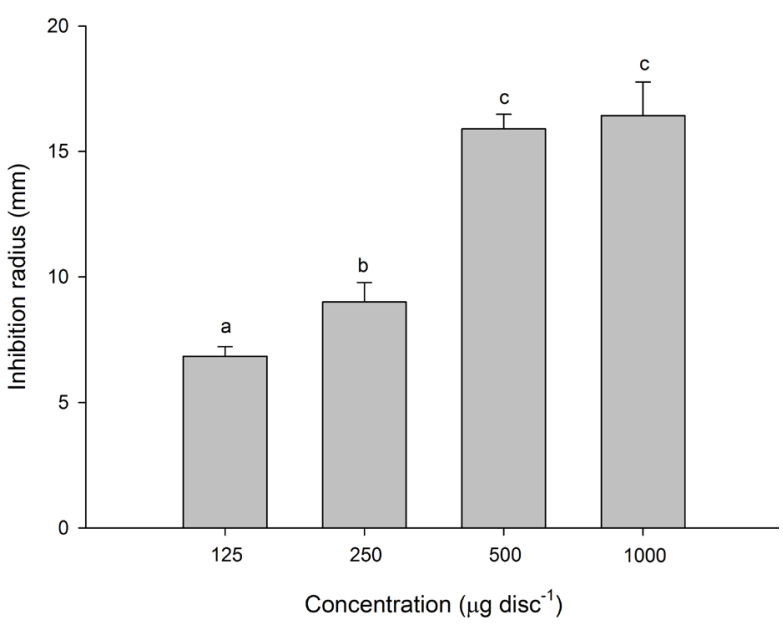

Figure 4 - Inhibition radius (mm) of Pithyum aphanidermatum exposed to different concentrations of Annona glabra extract (C group - 125, 250, 500 and $1000 \mu \mathrm{g} \mathrm{disc}{ }^{-1}$ ). At day 10, maximal inhibition zones were observed. Bars are means \pm SD for $n=3$, same superscript letters are not significantly different $(\mathrm{p}>0.05)$.

but as bioactive compounds, they can induce compensatory responses at the cellular level that can be beneficial. Standard algaecides such as $\mathrm{CuSO}_{4}$ are not likely to cause hormesis because copper is a micronutrient to microalgae. However, it can cause it in other organisms, e.g. the presence of copper stimulated the reproduction and growth of a freshwater cladoceran (De Schamphelaere and Janssen 2004). In our study, statistically higher growth rates were obtained at the concentrations of 25,125 , and $150 \mathrm{mg} \mathrm{L}^{-1}$, but not at the concentration of $75 \mathrm{mg} \mathrm{L}^{-1}$ of $A$. glabra extract, suggesting that a regulatory over-correction mechanism may have occurred. Nevertheless, more concentrations and higher exposure time should be tested to confirm the hormesis hypothesis for the organisms that we have tested.

Oomycetes were long considered a class within kingdom Fungi, but fundamental differences in physiology, biochemistry and genetics separate both groups (Latijnhouwers et al. 2003). Due to this separation, there are no specific anti-oomycetes substances developed and as an alternative, fungicides are used to control these organisms.

With the knowledge of some bryophytes such as Thuidium spp., Bryum spp. and Plagiochasma appendiculatum being effective against fungal strains (Bodade et al. 2008), as well the herbaceous plant Verbascum thapsus extracts inhibiting pathogenic fungi (Vogt et al. 2010), some recent studies tested different plant species extracts in oomycetes. Sánchez-Pérez et al. (2009) observed the inhibition of $50 \%$ of mycelial growth in the phytopathogenic Phytophthora cinnamomi in the presence of crude root extracts from Mexican avocado trees (Persea americana). In some studies using leaf extracts of 15 species of medicinal plants were observed the inhibition of Pythium debaryanum mycelia growth (Ambikapathy 2011, Pattnaik et al. 2012). Caruana et al. (2012) analyzed the activity of 24 crude plants extracts against Saprolegnia australis, a parasitic oomycete on fish and 12 extracts reduced growth at $100 \mathrm{mg} \mathrm{L}^{1}$, while 3 were effective at $10 \mathrm{mg} \mathrm{L}^{-1}$, while Jagtap et al. (2012) obtained inhibitions of $47 \%$ the mycelial growth of the phytopathogenic Phytophthora nicotianae using extracts of Allium sativum at 10\% concentration.

Annona glabra extracts inhibited $P$. aphanidermatum in concentrations higher than 125 $\mu \mathrm{g} \operatorname{disc}^{-1}$, with an apparent oomycestatic effect, comparable to fungicides as Cycloheximide and Bifonazole. In our study, A. glabra extracts in concentarions from 125 to $1000 \mu \mathrm{g} \mathrm{disc}{ }^{-1}$ were more effective against the oomycete with 6 to 16 $\mathrm{mm}$ inhibition zones radiuses, higher than leaf extracts from five medicinal plants at $10 \mu \mathrm{g} \mathrm{disc}^{-1}$ that inhibited Pythium debaryanum growth, with the higher values of $5 \mathrm{~mm}$ radius (Gomathi et al. 2011).

The ent-kaur-16-en-19-oic acid isolated from hexane extracts from A. glabra bark presented antifungal activity against 7 species (Padmaja et al. 1995), while stigmasterol and sitosterol isolated 
from Bulbine natalensis inhibited 3 species of fungi (Mbambo et al. 2012), but there are no specific antioomycetes activities recorded for these substances. We believe that these substances were responsible for the inhibition of the oomycete growth, but more studies are necessary with them separately to check if only one substance is responsible for the inhibition or if there is some synergism between them.

Based on our results, we believe that the ultrasound extraction used in the present study was effective, resulting in the isolation of 8 compounds present in A. glabra extracts using low amounts of A. glabra and solvents. Some of these compounds have algaecide and fungicide activities, and should be considered for more studies to identify the specific compound(s) responsible for algae and oomycete growth inhibition. Besides the algaecide activity, it was observed a stimulation in algal growth in some concentrations, maybe a "hormesis effect", however, more studies are needed to confirm this hypothesis. Considering the fact that A. glabra and oomycetes share flooded habitats, such antioomycete activity obtained from the acetone extract is an important evidence of plant - pathogen interaction and a potential species for the prospection of new substances for oomycete control. If we consider the higher costs with water treatment when there are algae blooms and the losses caused by oomycetes and fungi in the crops, the study of the compounds of Annona glabra can be economically and environmentally profitable.

\section{ACKNOWLEDGMENTS}

Maria da Graça Gama Melão is acknowledged for providing the sonicator and laboratory facilities. Conselho Nacional de Desenvolvimento Científico e Tecnológico (CNPq) (process 302837/20124) granted a research fellowship (RSM), GSR is grateful to Fundação de Amparo à Pesquisa do Estado de São Paulo (FAPESP) for the grant no.
2009/15511-5. J.P.N. Ribeiro is acknowledged for the photographs.

\section{REFERENCES}

AFNOR - ASSOCIATION FRANÇAISE DE NORMALISATION. 1980. Norme experimental T90304: Essais de eaux. Determination de L'inhibition de Senedesmus subspicatus par une substance. Paris.

ALLEN GM, BOND MD AND MAIN MB. 2002. 50 Common Native Plants Important In: Florida's Ethnobotanical History. University of Florida IFSA extensions.

AMBIKAPATHY V. 2011. Effect of antifungal activity of some medicinal plants against Pythium debaryanum (Hesse). Asian J Plant Sci Res 1(3): 131-134.

BARR D AND KEMP W. 1975. Olpidium brassicae, tobacco necrosis virus and Pythium spp. in relation to rusty root of carrots in Ontario and Quebec. Can Plant Dis Surv 55: 77-82.

BAYER. 2010. Safety data sheet "Lawn Weedkiller ready to use."

BAYER. 2012. Safety data sheet "FLC+PCH SC 62.5+625 G U-WW."

BODADE RG, BORKAR PS, SAIFUL-ARFEEN MD AND KHOBRAGADE CN. 2008. In vitro screening of Bryophytes for antimicrobial activity. J Med Plants 7(4): 23-28.

BRODERS K, LIPPS P, PAUL P AND DORRANCE A. 2007. Characterization of Pythium spp. associated with corn and soybean seed and seedling disease in Ohio. Plant Dis 91(6): 727-735.

CANTRELL CL, SCHRADER KK, MAMONOV LK, SITPAEVA GT, KUSTOVA TS, DUNBAR C AND WEDGE DE. 2005. Isolation and identification of antifungal and antialgal alkaloids from Haplophyllum sieversii. J Agric Food Chem 53: 7741-7748.

CARUANA S, YOON GH, FREEMAN MA, MACKIE JA AND SHINN AP. 2012. The efficacy of selected plant extracts and bioflavonoids in controlling infections of Saprolegnia australis (Saprolegniales; Oomycetes). Aquaculture 358-359: 146-154.

CEDERGREEN N AND STREIBIG JC. 2005. The toxicity of herbicides to non-target aquatic plants and algae: assessment of predictive factors and hazard. Pest Manag Sci 61: 1152-1160.

DE SCHAMPHELAERE KAC AND JANSSEN CR. 2004. Effects of chronic dietary copper exposure on growth and reproduction of Daphnia magna. Environ Toxicol Chem 23(8): 2038-2047.

DUKE SO, CANTRELL CL, MEEPAGALA KM, WEDGE DE, TABANCA N AND SCHRADER KK. 2010. Natural toxins for use in pest management. Toxins 2: 1943-1962. 
EBERLE M, ROTHROCK C AND CARTWRIGHT R. 2007. Pythium species associated with rice stand establishment problems in Arkansas. BR Wells Rice Research Studies AAES Research Series 560(6): 57-63.

EL-TARABILY KA, NASSAR AH, HARDY GE AND SIVASITHAMPARAM K. 2009. Plant promotion and biological control of Pythium aphanidermatum, a pathogen of cucumber, by endophytic actinomycetes. J Appl Microbiol 106(1): 13-26.

FIRDAUS MT, IZAM A AND ROSLI RP. 2010. Ultrasonicassisted extraction of triterpenoid saponins from mangrove leaves. In The 13th Asia Pacific Confederation of Chemical Engineering Congress, p. 1-8.

GOMATHI S, AMBIKAPATHY V AND PANNEESELVAM A. 2011. Antimicrobial activity of some medical plants against Pythium debaryanum (Hesse). J Microbiol Biotechnol 1(2): 8-13.

GROSS EM. 2003. Allelopathy of aquatic autotrophs. Critic Rev Plant Sci 22: 313-339.

HENDRIX FF AND CAMPBELL WA. 1973. Pythiums as plant pathogens. Annu Rev Phytopathol 11(1): 77-98.

HILT S AND GROSS EM. 2008. Can allelopathically active submerged macrophytes stabilise clear-water states in shallow lakes? Basic App Ecol 9(4): 422-432.

HU H AND HONG Y. 2008. Algal-bloom control by allelopathy of aquatic macrophytes - A review. Front Environ Sci Eng China 2: 421-438.

JAGTAP G, DHAVALE M AND DEY U. 2012. Evaluation of natural plant extracts, antagonists and fungicides in controlling root rot, collar rot, fruit (brown) rot and gummosis of citrus caused by Phytophtora spp. in vitro. Sci J Microbiol 1(2): 27-47.

JANČULA D, SUCHOMELOVÁ J, JAKUB G, SMUTNÁ M, MARŠÁLEK B AND TÁRBOSKÁ E. 2007. Effects of aqueous extracts from five species of the family Papaveraceae on selected aquatic organisms. Environ Toxicol 22(5): 480-486.

LATINJHOUWERS M, WIT PJGMDE AND GOVERS F. 2003. Oomycetes and fungi: similar weaponry to attack plants. Trends Microbiol 11(10): 462-469.

LIU XX, PILARINOU E AND MCLAUGHLIN JL. 1999. Pondaplin: A novel cyclic prenylated phenylpropanoid from Annona glabra. Tetrahedron Lett 40: 399-402.

LONZA. 2004. Safety data sheet "Barquat low foam algaecide."

LU CG, LIU WC, QIU JY, WANG HM, LIU T AND LIU DW. 2008. Identification of an antifungal metabolite produced by a potential biocontrol actinomyces strain A01. Braz J Microbiol 39: 701-707.

MACÍAS FA, GALINDO JLG, GARCÍA-DÍAZ MD AND GALINDO JCG. 2007. Allelopathic agents from aquatic ecosystems: potential biopesticides models. Phytochemistry Rev 7: 155-178.
MATA DI AND MORENO-CASASOLA P. 2005. Effect of in situ storage, light, and moisture on the germination of two wetland tropical trees. Aquat Bot 83: 206-218.

MATSUMOTO RS, RIBEIRO JPN, TAKAO LK AND LIMA MIS. 2010. Potencial alelopático do extrato foliar de Annona glabra L. (Annonaceae). Acta Bot Brasil 24: 631635.

MATSUMOTO RS, VARELA RM, PALMA M, MOLINILLO JMG, LIMA MIS, BARROSO CG AND MACÍAS FA. 2014. Bio-guided optimization of the ultrasound-assisted extraction of compounds from Annona glabra L. leaves using the etiolated wheat coleoptile assay. Ultrason Sonochem 21: 1578-1584.

MBAMBO B, ODHAV B AND MOHANLALL V. 2012. Antifungal activity of stigmasterol, sitosterol and ergosterol from Bulbine natalensis Baker (Asphodelaceae). J Med Plants Res 6(38): 5135-5141.

MENDONÇA FAC DE, SILVA KFS DA, DOS SANTOS KK, RIBEIRO JÚNIOR KAL AND SANT'ANA AEG. 2005. Activities of some Brazilian plants against larvae of the mosquito Aedes aegypti. Fitoterapia 76: 629-636.

MIELKE MS, MATOS EM, COUTO VB, ALMEIDA AAF, GOMES FP AND MANGABEIRA PAO. 2005. Some photosynthetic and growth responses of Annona glabra L. seedlings to soil flooding. Acta Bot Brasil 19: 905-911.

NRA - NATIONAL REGISTRATION AUTHORITY FOR AGRICULTURAL AND VETERINARY CHEMICALS. 2001. Public Release Summary - Evaluation of the new active semduramicin in the product aviax broad spectrum coccidiocidal feed additive premix. Canberra/ Australia.

NECHWATAL J AND MENDGEN K. 2007. Pythhium litorale sp. nov., a new species from the littoral of Lake Constance, Germany. FEMS Microbiol Lett 255(2006): 96-101.

PADMAJA V, THANKAMANY V, HARA N, FUJIMOTO Y AND HISHAM A. 1995. Biological activities of Annona glabra. J Ethnopharmacol 48: 21-24.

PATEKOSKI S, AMORIM L AND ZOTTARELLI P. 2010. Patogenicidade de Pythium aphanidermatum a alface cultivada em hidroponia e seu biocontrole com Trichoderma. Pesq Agropec Bras 1: 805-810.

PATTNAIK M, KAR M AND SAHU R. 2012. Bioefficacy of some plant extracts on growth parameters and control of diseases in Lycopersicum esculentum. Asian J Plant Sci Res 2(2): 129-142.

PAULITZ TC, ZHOU T AND RANKIN L. 1992. Selection of rhizosphere bacteria for biological control of Pythium aphanidermatum on hydroponically grown cucumber. Biol Control 2(3): 226-237.

PAWAR B. 2011. Antifungal activity of some stem extracts against seed-borne pathogenic fungi. J Phytol 3(4): 49-51.

PINTO ACQ, CORDEIRO MCR, ANDRADE SRM, FERREIRA FR, FILGUEIRAS HAC, ALVES RE AND 
KINPARADI. 2005. Annona species. $1^{\text {st }}$ ed., Southamptom: International Centre for Underutilised Crops, $284 \mathrm{p}$.

RIDGE I, WALTERS J AND STREET M. 1999. Algal growth control by terrestrial leaf litter: a realistic tool? Hydrobiologia 395: 173-180.

SALAMCI E, KORDALI S, KOTAN R, CAKIR A AND KAYA Y. 2007. Chemical compositions, antimicrobial and herbicidal effects of essential oils isolated from Turkish Tanacetum aucheranum and Tanacetum chiliophyllum var. chiliophyllum. Biochem Syst Ecol 35(9): 569-581.

SÁNCHEZ-PÉREZ JDL, JAIMES-LARA MG, SALGADOGARCIGLIA R AND LÓPEZ-MEZA JE. 2009. Root extracts from Mexican avocado (Persea americana var. drymifolia) inhibit the mycelial growth of the oomycete Phytophthora cinnamomi. Eur J Plant Pathol 124(4): 595601.

SETTER SD, SETTER MJ, GRAHAM MF AND VITELLI JV. 2008. Buoyancy and germination of pond apple (Annona glabra L.) propagules in fresh and salt water. In: Proceedings of the 16th Australian Weeds Conference, p. 140-142.

STEBBING A. 1982. Hormesis - the stimulation of growth by low levels of inhibitors. Sci Total Environ 22: 213-234.

STEBBING ARD. 1987. Growth hormesis: a by-product of control. Health Phys 52: 543-547.

SUGARS C, CHARLESTON K AND DOAK A. 2006. Pond apple management. Brisbane: Department of Natural Resources, Mines and Water.

TOPOROWSKA M, PAWLIK-SKOWROŃSKA B AND WOJTAL AZ. 2008. Epiphytic algae on Stratiotes aloides
L., Potamogeton lucens L., Ceratophyllum demersum L. and Chara spp. in a macrophyte-dominated lake. Oceanol Hydrobiol Stud 37: 51-63.

VAN WEST P, APPIAH AAAND GOW NAR. 2003. Advances in research on oomycete root pathogens. Physiol Mol Plant Pathol 6(2): 99-113.

VOGT V, CRAVERO C, TONN C, SABINI L AND ROSAS S. 2010. Verbascus thapsus: Antifungal and phytotoxic properties. Mol Med Chem 20: 105-108.

WANG H, HENG S, ZHANG S AND HE F. 2010. Chemical composition in aqueous extracts of Microcystis aeruginosa. Pol J Environ Stud 19: 213-218.

WU Z, GAO Y, WANG J, LIU B AND ZHU Q. 2009. Allelopathic effects of phenolic compounds present in submerged macrophytes on Microcystis aeruginosa. Allelopathy J 23: 403-410.

ZHANG S, SUN P, GE F AND WU Z. 2011. Different sensitivities of Selenastrum capricornutum and toxic strain Microcystis aeruginosa to exudates from two Potamogeton species. Pol J Environ Stud 20: 1359-1366.

ZHANG Y, PENG H, XIA G, WANG M AND HAN Y. 2004. Anticancer effect of two diterpenoid compounds isolated from Annona glabra Linn. Acta Pharmacol Sin 25: 937942.

ZHU J, LIU B, WANG J, GAO Y AND WU Z. 2010. Study on the mechanism of allelopathic influence on cyanobacteria and chlorophytes by submerged macrophyte (Myriophyllum spicatum) and its secretion. Aquat Toxicol 98: 196-203. 